\title{
Sustainable development and business process management
}

Alexandr L. Lisovsky ${ }^{1}$

1 The director general of JSC NPO Krypten

\section{ABSTRACT}

$\mathrm{B}$ relating BPM and Sustainability already exist, e.g. Green BPM is the sum of all management activities that help to monitor and reduce the environmental impact of business processes in their design, improvement, implementation, or operation stages, as well as lead to cultural change within the process lifecycle. The intention behind Green BPM is the incorporation of environmental objectives into the management of business processes. To achieve this objective, BPM has to be extended by ecologically oriented complements, as are the consideration of environmental strategy as a part of the process strategy, or the awareness for energy consumption and pollution. Together with an earlier article consolidates several contributions of the BPM foundations in three underlying process change traditions: (1) the Quality Control tradition, (2) the Business Management tradition, and (3) the Information Systems (IS) tradition. These three traditions propose different approaches to business process change and each emphasizes some practices over others. Currently, there is a tendency of combining the various traditions in a comprehensive BPM approach.

\section{KEYWORDS:}

Business Process Management (BPM), sustainable development, business processes, new technologies, the fourth industrial revolution, industrial company, Industry 4.0, innovations.

\section{FOR CITATION:}

Lisovsky A. L. Sustainable development and business process management. Strategic Decisions and Risk Management. 2019;10(3): 228-237. DOI: 10.17747/2618-947X-2019-3-228-237 


\title{
Применение инструментов управления бизнес- процессами для достижения устойчивого развития
}

А.Л. Лисовский ${ }^{1}$

${ }^{1}$ Генеральный директор АО НПО «Криптен»

\section{АННОТАЦИЯ}

\begin{abstract}
Y правление бизнес-процессами (ВРМ) до недавнего времени явно не фокусировалось на его применении для достижения целей устойчивого развития. Несмотря на то что подходы, связывающие ВРМ и устойчивое развитие, уже существуют, например, Грин (Green) указывал, что ВРМ помогает контролировать и сокращать влияние компании на изменение окружающей среды за счет объединения экологических целей и управления бизнес-процессами. Для достижения этой цели ВРМ должно быть дополнено экологически ориентированными целями и рассматривать экологическую стратегию как часть операционной стратегии. Вместе с более ранними исследованиями в данной статье рассматривается применение концепции ВРМ для трех ключевых направлений изменения бизнес-процессов: (1) Контроля качества, (2) Управления бизнесом, и (3) Информационных систем. Эти три направления предлагают разные подходы к изменению бизнес-процесса и, соответственно применение разных инструментов и методов. В настоящее время наблюдается тенденция объединения этих направлений изменений как концепция всестороннего подхода к ВРМ.
\end{abstract}

\section{КАЮЧЕВЫЕ САОВА:}

управление бизнес-процессами (ВРМ), устойчивое развитие, бизнес-процессы, новые технологии, четвертая промышленная революция, промышленные компании, Индустрия 4.0, инновации.

\section{АМЯ ЦИТИРОВАНИЯ:}

Лисовский А.Л. Применение инструментов управления бизнес-процессами для достижения устойчивого развития // Стратегические решения и риск-менеджмент. 2019. T. 10. № 3. С. 228-237. DOI: 10.17747/2618-947X-2019-3-228-237

\section{INTRODUCTION}

Today environmental problems are of particular importance both for the global society as a whole and for the business community. Organisations aimed to achieve long-term sustainability should take environmental aspects into account in the development of strategies, as well as in operational activities.

Business Process Management (BPM) increases in importance in the last decade and many organisations today draw their attention on identifying and documenting business processes, defining key performance indicators (KPIs) for measuring and controlling the performance of procceses, and taking different steps for continuous process improvement and innovation (Granetto B., Eid, 2013; Rosemann, 2014; vom Brocke, Rosemann, 2015; Zairi, 1997). It provides adequate techniques for the design, execution, controlling as well as the analysis of business processes in order to improve value creation within single organisations as well as in inter-organisational value networks (van der Aalst, ter Hofstede, 2005). According to Seidel, Recker, vom Brocke (2012), in their efforts to manage and improve business processes, BPM enables business benefits concerning costs, flexibility, time savings, quality, or, indeed, sustainable practices (Gallotta, Garza-Reyes, Anosike et al., 2016). However, sustainability is considered to be a multidimensional term and research needs to support aspects that are related to environmental and social concerns as well economic ones (Seidel, Recker, vom Brocke, 2012). Since information systems (IS) are deeply embedded into processes (Hedman, Henningsson, 2012), research on Green IS contributes to the reinvention of business and production processes towards sustainability (Butler 2011; Elliot 2011; Melville, 2010; Watson, Boudreau, Chen, 2010; Trachuk, Linder, 2015). 
Table 1

Overview of approaches to business process change

\begin{tabular}{|c|c|c|}
\hline QualityControl & $\begin{array}{c}\text { Business } \\
\text { Management }\end{array}$ & $\begin{array}{l}\text { Information } \\
\text { Systems }\end{array}$ \\
\hline $\begin{array}{l}\text { Taylor's Work } \\
\text { Simplification. } \\
\text { Quality movement } \\
\text { (TQM, Six Sigma, } \\
\text { Lean). } \\
\text { Capability Maturity } \\
\text { Models }\end{array}$ & $\begin{array}{l}\text { Porter's Value } \\
\text { Chain } \\
\text { Balanced Score } \\
\text { card }\end{array}$ & $\begin{array}{l}\text { Business Process } \\
\text { Reengineering. } \\
\text { Process Modelling } \\
\text { Tools. } \\
\text { Enterprise } \\
\text { Resource Planning } \\
\text { Applications. } \\
\text { Business Rules }\end{array}$ \\
\hline
\end{tabular}

According to Jeston and Nelis (2006), historically, research literature based on business process management has suggested that there are three critical aspects to a process improvement project: process, people, and technology. The BPM approach considers those three aspects comprehensively since process design needs to be linked to the company strategy and aiming to reach the process objectives; people are key to implement the proposed processes, they are the agents of change; technology means the tools that support processes and people, not necessarily means a BPM software or application (even though it could be) (Gallotta, Garza-Reyes, Anosike et al., 2016).

The BPM discipline calls for organisations to see themselves as a collection of highly integrated processes instead of a small set of functions and departments (McCormack, Johnson, 2001). Therefore, BPM is a comprehensive management approach to align business processes with corporate strategy, to analyse, to optimise and to implement best-in class processes.

Harmon's framework consolidates several contributions of the BPM foundations in three underlying process change traditions: (1) the Quality Control tradition, (2) the Business Management tradition, and (3) the Information Systems (IS) tradition. These three traditions propose different approaches to business process change and each emphasizes some practices over others. Currently, there is a tendency of combining the various traditions in a comprehensive BPM approach. Therefore, BPM is presented as a process change approach on top of the three underlying process change traditions (Table 1).

The Quality Control tradition is a continuation of Taylor's Work Simplification, and its systematic experimentation helps to identify the best way of performing tasks. Later on, Total Quality Management (TQM), Six Sigma and Lean followed. These approaches implement an organizational transformation that embraces processes throughout the organization. Subsequently, Capability Maturity Models (CMM) were developed, which initially focused on software applications, but are now generalized to entire companies. While the Quality Control tradition focuses on the quality and the production of products, the Business Management tradition considers a firm's overall performance.

The other tradition's emphasis is on strategic alignment and on managing employees to achieve corporate goals. Relevant frameworks within this tradition are Porter's Value Chains and the Balanced Scorecard. Thirdly, the IS tradition started with a primary focus on software automation. The Business Process Reengineering approach introduced process work. Such authors considered comprehensive processes, similar to Porter's Value Chains, but they simultaneously argued that the major force driv- ing business changes was IT. Later on, application-based process redesign approaches followed, such as Process Modelling Tools, Enterprise Resource Planning Applications, and Business Rules.

\section{BPM BENEFITS}

Rudden (2007) identified that the organisation that incorporates the BPM philosophy gains benefits in terms of Efficiency, Effectiveness and Agility. Efficiency usually is the first benefit to be observed by an organisation that deploys a BPM initiative. According to the author, most processes have a high level of waste because of manual labour, poor communication between departments and a general inability to control the progress as a whole. The initial deployment of a BPM solution eliminates these problems, and the benefit is typically expressed in full-time equivalent time saved. The efficiency can also be identified in the elimination of manual data entry, reduction of process cycle time and reduction of manual analysis. BPM tools may be pressed into roles beyond providing do-more-with-less efficiency. BPM tools offer the potential for greater business agility, as workflow apps can be quickly rolled out and modified to deal with shifting business trends or changes in the regulatory environment. Besides, some customers are looking to deploy BPM to enhance customer-facing processes as well as back-office tasks.

Once an organisation has realised that a more controlled process brings more capabilities, it will often concentrate on the development of effectiveness of the process. The returns are typically expressed in terms of making better decisions. One telecommunication service provider found that by better controlling their billing disputes process, they were able to reduce by $\$ 3$ million the amount they were paying out each quarter (approximately $10 \%$ ). Their business process management system helped them identify duplicate tasks, research disputes more thoroughly, and make their payout policies more consistent. The effectiveness can also be identified in handling exceptions faster and better and in making a more consistent execution of tasks.

According to Rudden (2007), the crucial third benefit that BPM provides is agility. Nowadays, a company's ability to adjust to the volatile business environment is vital. The drivers for changes can be internal or external, and new possibilities can arise, customers may change their demands. BPM provides a platform to change the organisation processes in a faster and controlled way. The agility can be identified in faster regulatory compliance and in supporting new business models.

Other authors (Jeston, Nelis, 2008; Scheer, 2006; Snabe, Rosenberg, Moller et al., 2008) identify other benefits obtained from BPM implementations, such as enablement of continuous process improvement, improvement of process quality, cost reduction, increase in the customer satisfaction, and better control over process performance.

\section{BPM SUCCESS FACTORS}

According to Jeston and Nelis (2008), BPM projects are usually complicated. This type of project has the potential to cross departments and, increasingly, organisation boundaries, as clients, vendors and partners become more involved. It will in- 
clude many diverse and complex stakeholder relationships both inside and outside the organisation. According to the authors, this type of initiatives has the following success factors: Leadership; Project Management alignment; Linkage to organisation strategy; Structured approach to implement BPM initiatives; People change management; People and empowerment; and Value Realisation.

Today, more organisations considering BPM in multiple business contexts (Harmon, 2016), although it is also observed more and more organisations reporting on project failure. Thus, much research has been carried out to analyse success factors for BPM (Ravesteyn, Batenburg, 2010; Trkman, 2010) and how these factors influence the different stages of BPM adoption (Buh, Kovačič, Indihar Štemberger, 2015). According to Benner and Tushman (2003), one reason for the frequency of BPM project failure is the lack of knowledge about how to sufficiently address the different contexts in which BPM is applied; or, in other words, BPM approaches, methods and models are not sensitive enough to diverse business contexts (vom Brocke, Zelt, Schmiedel, 2016).

\section{BUSINESS PROCESS MANAGEMENT (BPM) PHASES}

The literature provides numerous approaches to implement Business Process Management concepts in an organization. According to ABPMP (2009), the practice of business process management can be characterised as a constant lifecycle of BPM activities involved. While there are several modifications of BPM lifecycles, the vast majority of lifecycles can be summarised by an iterative, phased set of activities, which include (1) Planning, (2) Analysis, (3) Design and Modelling, (4) Implementation, (5) Monitoring and Control, and (6) Refinement (Gallotta Garza-Reyes, Anosike et al., 2016). As these business processes move through the lifecycle, they are enabled or constrained by a variety of factors including the four primary factors of Leadership, Values, Culture and Beliefs. Morais, Kazan, Dallavalle et al. (2014) showed a convergence of Business Process Management (BPM) models with the ABPMP reference model. The convergence is determined mainly in the models' intermediate steps: for the analysis, design and modelling, implementation and monitoring, control phases, the activities of studied models were mapped to the ABPMP (The Association of Business Process Management, 2009) BPM lifecycle. It was shown, that each step of the analyzed models matches to two or more steps of the ABPMP model or several steps of aexamined model correspond to a step of the reference model.

The success of transition towards sustainability is directly related to the alignment of the strategy and business processes in an explicit manner. This way, it was proposed a four phases framework (Analyse; Design; Implement; and Monitor \& Control), in which the Analyse phase has broken down the elements from the "process planning \& strategy" into the identification of business scenario, determination and prioritisation of processes, identification of project stakeholders, definition of project objectives, definition of metrics, record enterprise map, record baseline values and sustainability maturity assessment.
Intuitively, a well-accepted classification framework in the field of BPM could serve as a starting point to evaluate the scope of Green BPM techniques. Business process maturity models (BPMMs) seem to be appropriate candidates because they help organizations in developing BPM strategies and roadmaps to guide their ongoing process efforts. Therefore, as companies have a wide variety of activities, a BPMM should cover all capabilities in BPM. In the last decade, BPM researchers and practitioners have developed a long list of BPMMs with varied focus and depth. As only a limited set of BPMMs has been verified by sufficient empirical research, we opt for a classification scheme that distinguishes between technical and managerial capabilities.

Process improvements involve consecutive and iterative phases, which are often represented by a business process lifecycle. The traditional business process lifecycle relied on the established Plan-Do-Check-Act cycle and included the development of a strategy, definition and modelling, implementation, execution, monitoring and control, optimisation and improvement. The key changes that should be made to the traditional BPM life cycle for it to be ecological are defined in Nowak, Leymann, Schumm (2011), and this can be achieved by incorporating new elements or extending the traditional BPM. These new elements include the definition of a new stakeholder, the ecological officer, whose main function is to design the KPIs in accordance with the organisation's strategic objectives and define which methods will be used for measurement purposes and which strategy to follow in order to adapt the business process to these indicators. These authors consider that the use of a service-oriented architecture is appropriate as regards determining the various ecological metrics and correlating them with the information concerning the execution time of the business process. In the extension of the architecture, they add new services in order to determine ecological indicators, monitoring facilities, an ecology management dashboard, and methods and tools for the analysis and adaptation of ecological processes.

New patterns, classified as basic patterns (used over the business process, thus, signifying that it is not necessary to change the structure of the business processes), process-centred patterns (which change the structure of the process, along with the way in which the activities are carried out), and patterns focused on supply (which are focused on distributing the processes and activities among the associates with the aim of improving the global impact on the environment), are defined in Nowak, Leymann, Schumm (2011). The authors include suggestions concerning how to support the decisions made regarding the most suitable patterns to use in each case.

Another line of research concerns the cloud patterns associated with supporting the implementation and optimisation of business processes. In order to provide examples of the fact that an alternative could be the adaptation of known patterns, Nowak, Leymann, Schumm (2011) use variations of existing patterns for other domains (specifically, data flows, application architectures, and architectures in the cloud). The work in Nowak, Leymann, Schumm (2011), meanwhile, refers to four patterns that are focused on how to integrate the services implemented in order to construct an enterprise's value flow.

An extension of BPM to demonstrate how existing analysis tools for an organisation's management can be adapted in order to allow the inclusion of sustainability-related considerations is 
described in Recker, Rosemann, Gohar (2011). This extension makes it possible to indicate the impact of an activity on the emission of $\mathrm{CO}_{2}$, along with the "source of the emission" and the " $\mathrm{CO}_{2}$ production method"; attach a symbol representing a source of emission, such as fuel or paper, to each activity; use colour coding to provide information about how the emission of greenhouse gases is progressing or the final consumption for each swim lane or group created; and represent the flow of greenhouse gases in a process by connecting the emission-producing activities with emission indicators.

A framework that integrates sustainability with adaptive approaches for complexity and uncertainty, such that a company can be both adaptable and sustainable, is proposed in Peko, Dong, Sundaram (2014). The proposal includes the context, framework, life cycle, architecture, and prototype implementation, all of which form an adaptive sustainable business model. The authors highlight that a company of this type will have a resilient viewpoint, i.e., their products will be "built to last."

Information systems and information technologies support many business processes, and establishing the traceability of the business activity, the applications that support it and the hardware components that participate may, therefore, contribute to monitoring the use and consumption of this type of resources. A software prototype that implements a conceptual integration model in which the layers that participate (business process, application, and hardware) and the integration among them are clear is described in Reiter, Fettke, and Loos (2014).

One of the good practices employed in some businesses has been that of considering eco requirements at the same level as the requirements of the products and/or services that the business produces, thus enabling them to be inserted naturally into the process. One way in which to reflect this new type of requirements is to annotate the activities with the requirements.

Various authors tackle the importance of marking the activities with the quantity of $\mathrm{CO}_{2}$ emissions that they produce when they are executed or the resources that are used during their execution. Some of them, therefore, propose extensions to the BPMN.

Cappiello, Plebani, Vitali (2013) present an extension of the conceptual model of the business process in order to capture the energy consumed by business tasks. This is done by monitoring the components of a service centre in accordance with the Green performance indicators. This proposal makes it possible to identify where energy leaks or violations occur, thus facilitating improvements to processes. This annotation is not sufficient as regards considering all the possibly associated eco requirements. Some of them can be represented visually (e.g., emissions and energy consumption), while others are part of the detailed description of the activities, sub-activities, processes or businesses (e.g., good Green practices).

Another recurrent theme in various works is the use of information technology to strategically facilitate the reduction in carbon emissions of not only the information technology systems but also the entire organisation. Simulation as a technique by which to visualise how processes operate and the impact of changes are proposed in various research works.

A general conclusion regarding the process stages is that the most widespread tendency is that of adapting or extending already existing methods, techniques, and tools to BPM in order to support Green BPM.

\section{RELATING TO BUSINESS PROCESS MANAGEMENT (BPM) AND SUSTAINABILITY}

According to vom Brocke et al. (2012), business process management to date has not explicitly focused on sustainability as a change objective or driver. Although, approaches relating BPM and Sustainability already exist (Ghose et al., 2009; Hoesch-Klohe et al., 2010; Houy, Reiter, Fettke, 2012; Seidel, Recker, vom Brocke, 2012). According to Opitz, Krup, Kolbe (2014), green BPM is the sum of all management activities that help to monitor and reduce the environmental impact of business processes in their design, improvement, implementation, or operation stages, as well as lead to cultural change within the process lifecycle. The intention behind Green BPM is the incorporation of environmental objectives into the management of business processes. To achieve this objective, BPM has to be extended by ecologically oriented complements, as are the consideration of environmental strategy as a part of the process strategy, or the awareness for energy consumption and pollution (Houy, Reiter, Fettke, 2012).

According to Levina (2015), the majority of the sustainability initiatives focus on reducing the general resource usage (such as electricity), cost savings was the second exclusive goal mentioned by the enterprises, implying that the environmental benefits that result from the accordant activities are considered as a by-product of lean or optimisation actions rather than the goal itself, while providing a unique proposition to gain customers and market share. Process management techniques, especially techniques for process optimisation, are also shown to result in environmental benefits, i.e. resource usage or waste reduction, without being explicitly focused on designing green processes. As various industries are present in the study sample, indications about favoured managing techniques for green initiatives among the industries can deviate. It was observed that manufacturing companies tend to adopt lean and sustainable benefits but also that service oriented enterprise financially and environmentally benefit from conscious resource usage by applying and adopting the same techniques. According to Houy, Reiter, and Fettke (2012), Green BPM methods are still in the early stages and so far, only a few approaches exist.

Seidel, Recker, and vom Brocke (2012), for example, created a framework for Green BPM Research and Practice by building on a model of BPM capabilities. Essentially, the model describes a set of six capability areas that are key to the management of business processes in an organisation:

- Strategic Alignment is the continual tight linkage of business process management to organisational priorities and processes, enabling achievement of business goals.

- Governance establishes relevant and transparent accountability and decision-making processes to align rewards and guide actions in business process management.

- Methods are the approaches and techniques that support and enable consistent business process management actions and outcomes.

- Information Technology is the software, hardware, and information management systems that enable and support business process management activities. 
- People are the individuals and groups who continually enhance and apply their business process managementrelated expertise and knowledge.

- Culture is the collective values and beliefs that shape business process management-related attitudes and behaviours (Gallotta Garza-Reyes, Anosike et al., 2016).

Reiter, Fettke, and Loos (2014) introduce a combined approach of IT and BPM for efficient energy use in a process. The authors used a three-layer view that aims to introduce an integrated view of business processes, their related applications and the corresponding IT components. Houy, Reiter, and Fettke (2012) assessed and demonstrated both organisational and technological opportunities and challenges of Green BPM for the improvement of the sustainability of business activities. According to the authors in Green BPM, every business activity in a process model can be annotated with an adequate ratio representing the consumption of resources and the production of waste materials. By accumulating the annotated values, the total consumption of needed resources or the total production of waste materials in a process can be measured and controlled. This method facilitates an optimised organisation of activities in a process and the controlling of the ecological impact of its execution.

According to Houy, Reiter, and Fettke (2012), future research should further develop concepts for Green BPM; e.g. in the form of green reference process models or procedure models for the implementation of green processes. Furthermore, adequate techniques and tools for the realisation of Green BPM potentials in inter-organisational scenarios throughout the whole business process lifecycle can considerably contribute to more sustainable business activities.

The metrics definition is one critical aspect in the Sustainability Implementation Project since it is related to a few challenges to implementing those kinds of initiatives (select the right sustainability indicators, define the proper measurement method and align indicators to goals and objectives). According to Silvius, Schipper, Nedeski (2012), elaborating on the three perspectives of the triple bottom line concept, several organisations developed frameworks of indicators that would allow organisations to evaluate the sustainability aspects of different policies and projects, as well as to monitor progress. The literature on these models is a veritable jungle of different approaches and numerous case studies (Olsson, Hilding-Rydevik, Aalbu et al., 2004). A widely-used framework in sustainability reporting is the Sustainability Reporting Guidelines (SRG) by the Global Reporting Initiative (GRI). Companies can use the SRG to indicate to shareholders and consumers their economic, social and environmental performance. GRI's objective is to facilitate sustainability reporting for companies and thereby stimulate them to operate more sustainably. The SRG framework consists of an extensive set of indicators, from which companies can select a set that is relevant to their operations or industry (Silvius, Schipper, Nedeski, 2012).

GRI has indicators to provide information on the economic, environmental and social performance. According to The Sustainability Reporting Guidelines (2016), the economic dimension of sustainability concerns the organization's impacts on economic conditions of its stakeholders, and economic systems at local, national, and global levels. The environmental dimension of sustainability concerns the organisation's impact on living and non-living natural systems, including land, air, water and eco- systems. The Environmental Category covers impacts related to inputs (such as energy and water) and outputs (such as emissions, effluents and waste). Besides, it covers biodiversity, transport, and product and service-related impacts, as well as environmental compliance and expenditures; and the social dimension of sustainability concerns the impacts the organisation has on the social systems within which it operates. According to the The Sustainability Reporting Guidelines (2016), there are 91 indicators and many of them can be used as metrics and evaluate the performance in the business processes, e.g. "direct economic value generated and distributed', 'proportion of spending on local suppliers at significant locations of operation', 'energy consumption within the organisation', 'reduction of energy consumption', 'direct Greenhouse Gas (GHG) emissions', 'operations with significant actual and potential negative impacts on local communities'.

So, depending on what are the goals of the project, different metrics can be adopted. For example, a company can define 'Increase flexibility', 'reduce water consumption', 'reduce energy consumption' and 'increase health and safety standards' as metrics to be measured along with the project. All those metrics will be evaluated and associated with relevant processes or activities and later will be monitored along with the project. The intention to that is to be possible to assess the performance of those metrics in the beginning and comparing it to the final stage, displaying the evolution of the metrics and showing the sustainability impact of the project (Gallotta, Garza-Reyes, Anosike et al., 2016).

\section{SUSTAINABILITY IMPLEMENTATION PROBLEMS}

Many organisations are committed to transforming their business processes and have taken sustainability initiatives. However, they have still failed to achieve the anticipated goal (Ahmed, Sundaram, 2012). Every sustainability project involves changes in the organisation, from the most basic ones (like replacing disposal plastic cups for individual ceramic mugs) up to changes in the company operations. However, according to Burnes (2003), between 40 and 70 percent of these change initiatives still fail. Those initiatives fail due to many different reasons, either the lack of management support, lack of proper communication, lack of stakeholder engagement, among others.

However, the reasons behind the initiatives' failure might be in the challenges to implement sustainability initiatives. Once an organisation does not overcome a particular challenge, it might fail this initiative. A few authors (such as Epstein et al., 2010; Frandsen, Morsing, Valletin, 2013, Seidel, Recker, vom Brocke, 2012; Giunipero, Hooker, Denslow, 2012) have studied those barriers. According to Epstein et al. (2010), the challenges of implementing sustainability initiatives are setting clear and measurable goals, dealing with financial incentive pressures; and comprehending Stakeholder reactions. Seidel, Recker, vom Brocke (2012) suppose that the challenge arises on how sustainability considerations (such as carbon footprint, renewable energy consumption, wastage production, and other environmental performance indicators) can be considered in the management of an organisation's processes. Frandsen, Morsing, Valletin (2013) pro- 
Table 2

Summary of some challenges found in the literature to implement sustainability initiatives

\section{References}

Epstein, Buhovac (2010)

Seidel, Recker, vom Brocke (2012)

Giunipero, Hooker, Denslow (2012) Ahmed\&Sundaram
$(2012)$

Poveda, Lipsett (2014)

Frandsen, Morsing, Valletin (2013)

Stewart et al. (2016)

\section{Challenges}

Setting clear and measurable goals. Dealing with financial incentive pressures. Comprehending stakeholder reactions

How to consider sustainability aspects in the management of an organisation's processes

Lack of consensus at the CEO level. Costs of sustainability and economic conditions.Lack of sustainability standards and appropriate regulations. Misalignment of short term and long term strategic goals

Existing roadmaps, frameworks and systems do not comprehensively support sustainable business transformation. Existing systems do not allow decision makers to explore interrelationships and influences between the sustainability dimensions. Sustainability concept continues to be applied unsystematically

Select the right sustainability Indicators. Define the proper measurement method. Align indicators to goals and objectives

How to embed sustainability to the organization

The barriers are categorised in (1) internal, such as financial and other resource constraints, managerial and employee attitudes, poor communication and past practices, and (2) external, such as capital costs, competitive pressures, industry regulation, technical information, green market opportunities and technical solutions

pose that the main challenge is to embed sustainability into the organisation. According to Poveda, Lipsett (2014), the challenge lies in the sustainability indicators, specifically in selecting the right indicators, identifying the measurement method and aligning them to the goals and objectives of the project. The main barriers to the sustainability adoption are (1) lack of consensus at the CEO level, (2) costs of sustainability and economic conditions, (3) lack of sustainability standards (covering all the three aspects from the Triple Bottom Line) and appropriate regulations, and (4) misalignment of short term and long term strategic goals (Giunipero, Hooker, Denslow, 2012).

Ahmed and Sundaram (2012) go even beyond the presented challenges, according to the authors existing roadmaps, frameworks and systems do not comprehensively support a sustainable business transformation nor do they allow decision-makers to explore interrelationships and influences between the sustainability dimensions. However, because the sustainability concept continues to be applied unsystematically, these practicing organisations experience considerable difficulties in realising their goals of full sustainability status. This is due to a lack of understanding and support for the design, development and implementation process, and lack of proper procedural and technological support for decision making for sustainability management.
Stewart et al. (2016) categorise the barriers in (1) internal barriers, such as financial and other resource constraints, managerial and employee attitudes, poor communication and past practices and (2) external barriers, such as capital costs, competitive pressures, industry regulation, technical information, green market opportunities and technical solutions. Table 2 represents the summary of some challenges found in the literature to implement sustainability initiatives.

\section{THE IMPACT OF INDUSTRY 4.0 ON BPM}

Information technologies play a major role in Green BPM, and this is especially noticeable with the development of technology Industry 4.0. Below are the key advantages that might be possible through the use of Industry 4.0 technologies (Trachuk, Linder, Tarasov et al., 2018).

Using resources and optimizing processes. The possibilities to improve processes and the consumption of materials when using the concepts of Industry 4.0 are versatile. It is possible to decrease material costs by less defective goods and optimize processes (in speed or yield) via the use of cyber-physical systems, which allow the observation of processes in real-time. Through the use of these technologies, it will be possible to react to events in the physical world in an automatic and fast way. Therefore, the improvement of manufacturing processes, including the optimization of material consumption will drive value and will make it possible to increase productivity by $3-5$ percent.

Utilization of assets. The optimal use of a companies' machinery park is supported by Industry 4.0 based technologies, which enable for example, predictive maintenance. Through the permanent, remote monitoring of machinery conditions, it becomes possible to reduce machine downtimes or changeover times by early detection of possible problems and continuous maintenance. Therefore, the avoidance and early correction of defects can save costs and drive production throughput, which consequently drives value. According to analyses, the use of predictive maintenance enables to decrease total machine downtime by $30-50 \%$ and to increase machine life by $20-40 \%$.

Labour productivity. An increase in the productivity of labour can significantly drive value. The improvement of labour productivity can be realized by using the new technologies of Industry 4.0, which make it possible, e.g. to reduce waiting times between different production steps in manufacturing or by accelerating the R\&D process (e.g., through 3D-printing). Furthermore, the burden or complexity of tasks can increase the speed of manual production steps executed by workers. An example of such assistance within production processes is the German company Festo, where human-robot collaborations work close to each other.

Management of inventories. A proper management of inventories is essential, because too much inventory leads to high capital costs. By applying Industry 4.0 levers, drivers of excess inventories can be targeted by addressing problems like unreliable demand planning and overproduction. This becomes possible, e.g. through real-time supply chain optimization. 
Through technologies like systems which automatically reorder if necessary, costs for inventory holding can be reduced by $20-50 \%$.

Quality improvement. Industry 4.0 applications facilitate the improvement of product and process quality by using real-time problem solving, advanced process control or real-time error corrections to decrease unstable manufacturing processes, rework and consequently extra costs (The outlook, 2015, p. 26). By using these approaches, a saving of costs related to the suboptimal quality of about $10-20 \%$ could be achieved. For example, Siemens was able to decrease the defect rate to a minimum through the use of advanced technologies emerging with the fourth industrial revolution.

Match of supply and demand. To prevent from waste by unnecessary inventory and storage cost, a perfect understanding of customer demand in terms of quantity and product features lead to much better predictability through new possibilities like crowd forecasting based on advanced analytics. The use of such technologies can increase the accuracy of demand forecasting to more than $85 \%$.

Reducing time to market. Being the first supplier on the market with a new product can create value in terms of increased revenues and less competition. New technologies emerging with Industry 4.0 enabling faster and cheaper $\mathrm{R} \& \mathrm{D}$ processes, e.g. concurrent engineering or rapid prototyping by using 3D-printing can significantly reduce the time to market. The use of such technologies can reduce the time to market by $30-50 \%$.

Service and aftersales. Innovative services lead to new possibilities of repairing products and to the chance to keep them longer operational. Product manufacturing can be more cost-effective, when machines get a longer operational time. This is possible e.g. through remote maintenance or virtually guided self-service. In this case, it is possible to carry out error diagnosis and even repair without the necessity of a technician visiting the site. In average maintenance costs could be reduced by about $10-40 \%$ through the use of remote and predictive maintenance.

This article aims to identify and systematize factors that influence the development of the concept of green business process management in the context of sustainable development of an organization. The importance of taking into account the principles of green business process management is determined by sustainable development goals. In spite of the fact that attempts are being made to introduce green business processes into the activities of companies, often such initiatives fail. Researchers identify barriers to implementing green BPMs, but they tend to be united by a lack of clearly defined goals, a common understanding of the target picture and a lack of resources. Nevertheless, the benefits of introducing green BPM in the context of digitalization of the economy are obvious and include not only improving the quality of the organization's internal processes, but also economic effects.

\section{REFERENCES}

1. Trachuk A. V., Linder N. V. (2015). Perekhod k ustojchivomu razvitiyu kak predmet issledovaniya // Upravleniye ustojchivym razvitiyem. SPb.: Real'naya ekonomika. S. 12-34. [Trachuk, A. V., Linder, N. V. (2015) Transition to sustainable development as a subject of research. In: Sustainable development management. St Petersburg: Real Economy Publishing House. 12-34. (In Russ.)].

2. Trachuk A.V., Linder N.V., Tarasov I.V. i dr. (2018). Transformatsiya promyshlennosti $\mathrm{v}$ usloviyakh chetvertoj promyshlennoj revolyutsii/Pod red. prof. A.V. Trachuka. SPb.: Real'naya ekonomika. 146 s. [Trachuk, A. V., Linder, N. V., Tarasov, I. V. et al. (2018). Industrial Transformation in the Fourth Industrial Revolution, ed. by prof. A.V. Trachuk. St Petersburg: Real Economy Publishing House. 146 p. (In Russ.)].

3. Ahmed, M. D., Sundaram, D. (2012) Sustainability modelling and reporting: From roadmap to implementation. Decision Support Systems. 53 (3):611-624. DOI: 10.1016/j. dss.2012.02.004.

4. Benner, M., Tushman, M. (2003). Exploitation, Exploration, and Process Management: The Productivity Dilemma Revisited. The Academy of Management Review. 28 (2):238-256. DOI:10.2307/30040711.

5. Buh, B., Kovačič, A., Indihar Štemberger, M., (2015). Critical success factors for different stages of business process management adoption - a case study. Economic Research-Ekonomska Istraživanja. 28:243-258. DOI: 10.1 080/1331677X.2015.1041776.

6. Burnes, B. (2003). Managing change and changing managers from ABC to XYZ. Journal of Management Development. 22 (7):627-642. DOI: https://doi.org/10.1108/0262171031 0484768 .

7. Butler, T. (2011). Compliance with institutional imperatives on environmental sustainability: Building theory on the role of Green IS. The Journal of Strategic Information Systems. 20 (1):6-26. DOI: 10.1016/j.jsis.2010.09.006.

8. Cappiello, C., Plebani, P., Vitali, M. Energy-Aware Process Design Optimization. In: Proceedings of the International Conference on Cloud and Green Computing, Karlsruhe, Germany, 30 September - 2 October 2013. 451-458. DOI: 10.1109/CGC.2013.77.

9. Elliot, S. (2011). Transdisciplinary perspectives on environmental sustainability: A resource base and framework for IT-enabled business transformation. MIS Quarterly. 35 (1):197-236. DOI: $10.2307 / 23043495$.

10. Epstein, M. J.. Buhovac, A. R. (2010) Solving the sustainability implementation challenge. Organisational Dynamics. 39:306-315. DOI: http://dx.doi.org/10.1016/j. orgdyn.2010.07.003.

11. Frandsen, S., Morsing, M., Valletin, S. (2013) Adopting sustainability in the organization: Managing processes of productive loose coupling towards internal legitimacy. Journal of Management Development. 32 (3):236-246. DOI: https://doi.org/10.1108/02621711311318265.

12. Gallotta, B., Garza-Reyes, J. A., Anosike, A., et al. (2016). A conceptual framework for the implementation of sustainability business processes. In: Proceedings of the 27th Production and Operations Management Society (POMS) Conference, Orlando, FL, US, May 6-8.

13. Granetto, B., Eid, T. (2013). Market Share Analysis: Enterprise Content Management, Worldwide, 2012//Gartner. https://www.gartner.com/en/documents/2474215/marketshare-analysis-enterprise-content-management-worl. 
14. Giunipero, L., Hooker, R., Denslow, D. (2012). Purchasing and supply management sustainability: Drivers and barriers. Journal of Purchasing and Supply Management. 18 (4):258269. DOI: https://doi.org/10.1016/j.pursup.2012.06.003.

15. Guide to the Business Process Management Body of Knowledge (BPM CBOK) (2009). ABPMP. https://www. abpmp-br.org/educacao/bpm-cbok/.

16. Harmon, P. (2016). The State of Business Process Management. BPtrends. https://www.bptrends.com/bpt/wpcontent/uploads/2015-BPT-Survey-Report.pdf.

17. Hedman, J., Henningsson, S. (2012). Green IT: Sustainability from a Information Systems Perspective. CBS Sustainability Quarterly. 3:29-31.

18. Hoesch-Klohe, K., Ghose, A. (2010). Business process improvement in Abnoba. In: Proceedings of the 1st international workshop on services, energy, \& ecosystem (SEE 2010). San Francisco, CA.

19. Houy, C., Reiter, M., Fettke, P. (2012). Advancing Business Process Technology for Humanity: Opportunities and Challenges of Green BPM for Sustainable Business Activities. In: Seidel, S., Recker, J., vom Brocke, J. Green Business Process Management: Towards the Sustainable Enterprise. Heidelberg: Springer. 15-37.

20. Jeston, J., Nelis, J. (2006). Business Process Management Practical Guidelines to Successful Implementations. Oxford: Elsevier

21. Jeston, J., Nelis, J. (2008). Management by process: A roadpmap to sustainable Business Process Management. Amsterdam: Elsevier/Butterworth-Heinemann.

22. Levina, O. (2015). Exploring the Role of Business Process Management in Sustainability Initiatives. In: MCIS 2015 Proceedings. 35. http://aisel.aisnet.org/mcis2015/35.

23. McCormack, K. P., Johnson, W. C. (2001). Business Process Orientation: Gaining the E-Business Competitive Advantage. Boca Raton, FL: CRC Press. 208 p.

24. Melville, N. P. (2010). Information systems innovation for environmental sustainability. MIS Quarterly. 34 (1):1-21.

25. Morais, R., Kazan, S., Dallavalle, S. et al. (2014). An analysis of BPM lifecycles: from a literature review to a framework proposal. Business Process Management Journal. 20 (3):412-432. DOI: 10.1108/BPMJ-03-2013-0035.

26. Nowak, A., Leymann, F., Schumm, D. (2011). The Differences and Commonalities between Green and Conventional Business Process Management, Dependable,
Autonomic and Secure Computing (DASC). In: IEEE Ninth International Conference on Dependable, Autonomic and Secure Computing, DASC 2011, 12-14 December 2011, Sydney, Australia. Sydney. DOI: 10.1109/DASC.2011.105.

27. Olsson, J. A., Hilding-Rydevik, T., Aalbu, H. et al. (2004). Indicators for Sustainable Development. In: European Regional Network on Sustainable Development. Discussion paper. Cardiff, 23-24 March 2004. Cardiff, 2004.

28. Opitz, N., Krup, H., Kolbe, L. M. (2014). Green Business Process Management - A Definition and Research Framework. In System Sciences (HICSS), 2014 47th Hawaii International Conference on. IEEE. 3808-3817.

29. Peko, G., Dong, C.-S., Sundaram, D. (2014). Adaptive Sustainable Enterprises Mobile Networks and Applications. 19 (5):608-617. DOI: 10.1007/s11036-014-0525-8.

30. Poveda, C., Lipsett, M. (2014). An integrated approach for sustainability assessment: the $\mathrm{Wa}-\mathrm{Pa}-\mathrm{Su}$ project sustainability rating system. International Journal of Sustainable Development \& World Ecology. 21 (1):85-98. DOI: 10.1080/13504509.2013.876677.

31. Ravesteyn, P., Batenburg, R. (2010). Surveying the critical success factors of BPMsystems implementation. Business Process Management Journal. 16 (3):492-507. DOI: 10.1108/14637151011049467.

32. Recker, J., Rosemann, M., Gohar, E. R. (2011). Measuring the Carbon Footprint of Business Processes. Business Process Management Workshops. January. 511-520. FOI:https://doi.org/10.1007/978-3-642-20511-8_47.

33. Reiter, M., Fettke, P., Loos, P. (2014). Towards Green Business Process Management: Concept and Implementation of an Artifact to Reduce the Energy Consumption of Business Processes. In: System Sciences (HICSS), 2014 47th Hawaii International Conference on: IEEE. 885-894. DOI: 10.1109/HICSS.2014.117.

34. Rosemann, M., vom Brocke, J. (2015). The six core elements of business process management. In: J. vom Brocke, M. Rosemann (Eds.). Handbook on business process management: Introduction, methods and information systems. 1:107-122.

35. Rudden, J (2007). Making the Case for BPM: A Benefits Checklist. BPTrends. 1-8.

36. Scheer, A. (2006). Agility by Aris business process management. Berlin: Springer.

37. Seidel, S., Recker, J., vom Brocke, J., (2012). Green 
Business Process Management: Towards the Sustainable Enterprise. Heidelberg: Springer.

38. Silvius, A.J. G., Schipper, R, Nedeski, S (2012) Sustainability in Project Management: Reality Bites. In: 26th World Congress of the International Project Management Association (IPMA). Crete. 1053-1061.

39. Snabe, J. H., Rosenberg, A., Moller, C. et al. (2008). Business Process Management - The SAP Roadmap. Boston: Galileo Press Inc.

40. Stewart, H., Gapp, R. P. (2016) Achieving Effective Sustainable Management: A Small-Medium Enterprise Case Study. Corporate Social Responsibility and Environmental Management. 21 (1). DOI: 10.1002/csr.1305.

41. The outlook for global growth in 2015 (2015). McKinsey. https:/www.mckinsey.com/business-functions/strategyand-corporate-finance/our-insights/the-outlook-for-globalgrowth-in-2015.

42. The Sustainability Reporting Guidelines (2016). GRI. https:/www.globalreporting.org/standards/gri-standardsdownload-center/.

43. Trkman, P. (2010). The critical success factors of business process management. International Journal of Information Management. 30:125-134. DOI: 10.1016/j. ijinfomgt.2009.07.003.

44. van der Aalst, W.M. P., ter Hofstede, A.H. M. (2005). YAWL: Yet another workflow language. Information Systems. 30 (4):245-275. DOI: 10.1016/j.is.2004.02.002.

45. vom Brocke J., Mathiassen L., Rosemann, M. (2014). Business Process Management. Business \& Information Systems Engineering. 6 (4):189. DOI: 10.1007/s12599-0140330-8.

46. vom Brocke J., Rosemann M. (eds.) (2015). Handbook on business process management. Berlin: Springer. 237 p.

47. vom Brocke, J., Zelt, S., Schmiedel, T. (2016). On the Role of Context in Business Process Management. International Journal of Information Management. 36 (3):486-495. DOI: 10.1016/j.ijinfomgt.2015.10.002.

48. Watson, R. T., Boudreau, M. C., Chen, A. J. (2010). Information systems and environmentally sustainable development: Energy informatics and new directions for the IS community. MIS Quarterly. 34 (1):23-38. DOI: 10.2307/20721413.

49. Zairi, M. (1997). Business process management: a boundaryless approach to modern competitiveness. Business Process Management Journal. 3(1):64-80. DOI: https://doi. org/10.1108/14637159710161585.

\section{ABOUT THE AUTHOR}

\section{Alexandr L. Lisovsky}

$\mathrm{PhD}$ in Economics, the director general of JSC NPO Krypten Research interests: formation of strategy of development of the industrial companies, management of changes, transformation of industrial production.

E-mail: al@aspp.ru

\section{ИНФОРМАЦИЯ ОБ АВТОРЕ}

\section{А.Л. Лисовский}

Кандидат экон. наук, генеральный директор АО НПО «Криптен»

Сфера научных интересов: стратегии развития промышленных компаний, управление изменениями, трансформация промышленных компаний.

E-mail: al@aspp.ru 